\title{
Characterization of two urostylid ciliates, Metaurostylopsis flavicana spec. nov. and Tunicothrix wilberti (Lin \& Song, 2004) Xu et al., 2006 (Ciliophora, Stichotrichia), from a mangrove nature protection area in China
}

Correspondence
Xiaozhong Hu
xiaozhonghu@ouc.edu.cn

\author{
Yangang Wang, ${ }^{1}$ Xiaozhong Hu, ${ }^{1,2}$ Jie Huang, ${ }^{1}$ Khaled A. S. Al-Rasheid $^{3}$ \\ and Alan Warren ${ }^{2}$
}

\author{
${ }^{1}$ Laboratory of Protozoology, Institute of Evolution and Marine Biodiversity, Ocean University of \\ China, Qingdao 266003, PR China \\ ${ }^{2}$ Department of Zoology, Natural History Museum, Cromwell Road, London SW7 5BD, UK \\ ${ }^{3}$ Zoology Department, King Saud University, PO Box 2455, Riyadh 11451, Saudi Arabia
}

\begin{abstract}
Two marine stichotrich ciliates, Metaurostylopsis flavicana spec. nov. and Tunicothrix wilberti (Lin \& Song, 2004) Xu et al., 2006, isolated from the Shenzhen Mangrove Protection Area on the coast of the South China Sea, were investigated using live observation and protargol impregnation techniques. Metaurostylopsis flavicana is characterized by its elongate body shape, yellowish body colour and bright-yellow cortical granules that are either grouped around the cirri and the dorsal cilia or aligned between the rows of cirri and dorsal cilia. It has four to eight frontal, two frontoterminal, one buccal and seven to ten transverse cirri, a mid-ventral complex comprising 13-17 midventral cirral pairs in a row that extends about three-fifths of the body length, four left and three right marginal rows and three complete dorsal kineties. The small subunit rRNA gene of this species was sequenced and phylogenetic trees were constructed in which M. flavicana does not group with its congeners, suggesting that the genus Metaurostylopsis is paraphyletic. Some supplementary morphological and morphogenetic traits for Tunicothrix wilberti are also documented.
\end{abstract}

\section{INTRODUCTION}

Urostylid ciliates, characterized by the zigzag arrangement of the cirri in the midventral complex, are common in various biotopes worldwide (Kahl, 1932; Berger, 2006). Considering the fact that many forms discovered recently in seas off northern China are new, the species diversity of this group is probably greater than previously estimated (Song et al., 2001; Hu et al., 2002; Lei et al., 2005; Xu et al., 2006; Shao et al. 2008a, b).

The genus Metaurostylopsis was established by Song et al. (2001) with Metaurostylopsis marina as the type species by original designation. Subsequently, five more species have been described (Song et al., 2001; Lei et al., 2005; Wilbert \& Song, 2005; Berger, 2006; Shao et al., 2008a, b).

Abbreviations: AZM, adoral zone of membranelles; BI, Bayesian inference; ML, maximum-likelihood; MP, maximum-parsimony; SSU, small subunit.

The GenBank/EMBL/DDBJ accession number for the SSU rRNA gene sequence of Metaurostylopsis flavicana is FJ775718.
Morphogenesis has been reported in varying levels of detail for M. marina, Metaurostylopsis rubra and Metaurostylopsis sinica (Song et al., 2001; Wilbert \& Song, 2005; Shao et al., 2008a) and the phylogeny of M. rubra, Metaurostylopsis salina and Metaurostylopsis struederkypkeae was discussed by Yi et al. (2008) based on small subunit (SSU) rRNA gene sequence data.

Tunicothrix is characterized by the presence of a conspicuous cortical alveolar layer, a bipartite adoral zone of membranelles (AZM) and a few midventral cirri that are arranged in pairs and restricted to the frontal region immediately anterior of the midventral row ( $\mathrm{Xu}$ et al., 2006). There are two known species, Tunicothrix rostrata and Tunicothrix wilberti.

In the present study, two ciliate morphotypes were isolated from the Shenzhen Mangrove in southern China. Subsequent observations of their morphology both in vivo and following protargol impregnation revealed that they represent a previously unknown species of Metaurostylopsis, Metaurostylopsis flavicana spec. nov., and T. wilberti, which 
hitherto has only been reported from coastal regions of the Yellow Sea in northern China (Lin \& Song, 2004). One cell at the divisional stage was opportunistically observed for $M$. flavicana. The systematic position of each species is discussed in the light of SSU rRNA gene sequence data (for M. flavicana) and morphogenetic data (for T. wilberti).

\section{METHODS}

M. flavicana and T. wilberti were collected on 3 January 2008 and 26 December 2007, respectively, from the Shenzhen Mangrove Nature Protection Area $\left(22^{\circ} 37^{\prime} \mathrm{N} 114^{\circ} 04^{\prime} \mathrm{E}\right)$. In both cases, the water temperature was about $17{ }^{\circ} \mathrm{C}$ and the salinity was $20 \%$. Glass slides were used as artificial substrates to collect ciliates. Briefly, the slides were retrieved after being immersed in water for about 7-10 days and transferred to Petri dishes with seawater from the sampling site. Attempts to culture the two species failed; therefore, all studies were carried out on freshly isolated specimens. Individuals were observed in vivo using differential interference contrast microscopy. Protargol staining (Wilbert, 1975) was used in order to reveal the infraciliature. Counts and measurements of stained specimens were performed at $\times 1000$ magnification. Drawings were made with the help of a camera lucida. Terminology is according to Berger (2006) and $\mathrm{Xu}$ et al. (2006) and the systematic arrangement mainly follows Lynn (2008).

Genomic DNA extraction, PCR amplification and sequencing of the SSU rRNA gene from $M$. flavicana were performed according to $\mathrm{Hu}$ et al. (2009). The SSU rRNA gene sequences used for analysis were obtained from GenBank (for accession numbers, see Fig. 3). Phacodinium metchnikoffi was selected as the outgroup species. Following preliminary analysis, it was decided to omit sequences of choreotrichs and oligotrichs, because their inclusion in alignments and trees in the present study resulted in unstable topologies; for example, Holosticha species were placed in either the choreotrich or oligotrich clades in some trees.

Three different methods were employed to compute phylogenetic trees: Bayesian inference (BI), maximum-likelihood (ML) and maximum-parsimony (MP). Sequences were aligned using the CLUSTAL $\mathrm{W}$ program implemented in BioEdit 7.0.0 with default settings (Hall, 1999). The alignment was further modified manually and 1834 characters were used in the final analyses. The program MrModeltest 3.7 (Nylander, 2004) selected GTR $+\mathrm{I}+\mathrm{G}$ as the best model with the Akaike information criterion, which was then used for BI and ML analyses. BI analysis was performed with MrBayes 3.1.2 (Ronquist \& Huelsenbeck, 2003). Markov chain Monte Carlo simulations were then run with two sets of four chains using the default settings: chain length 10000000 generations, with trees sampled every 100 generations. The first 2500 generations were discarded as burn-in. The remaining trees were used to generate a consensus tree and calculate the posterior probabilities of all branches using a majority-rule consensus approach. An ML tree was constructed with PhyML version 2.4.4 (Guindon \& Gascuel, 2003). The reliability of internal branches was assessed using a nonparametric bootstrap method with 1000 replicates, a variable-site gamma distribution shape parameter $(G)$ of 0.4352 and the proportion of invariable sites (I) set to 0.5033 . MP analysis was performed with the software package PAUP* $4.0 \mathrm{~b} 10$ (Swofford, 2002) and support for the internal branches was estimated using the bootstrap method with 1000 replicates.

TreeView version 1.6.6 (Page, 1996) and MEGA 3.1 (Kumar et al., 2004) were used to visualize tree topologies. Trees were edited for aesthetic purposes with MEGA.

\section{RESULTS AND DISCUSSION}

\section{Metaurostylopsis flavicana spec. nov. (Figs 1, 2 and 3; Tables 1 and 2)}

Diagnosis. Marine Metaurostylopsis, 130-200 × 30-60 $\mu \mathrm{m}$, with slender body shape; yellowish in colour; bright-yellow cortical granules either arranged in lines between the rows of ventral cirri and dorsal cilia or grouped around these cirri and cilia. Thirty-three to 45 adoral membranelles, four to eight frontal, two frontoterminal, one buccal and seven to ten transverse cirri; 13-17 midventral cirral pairs extending to posterior two-fifths of the body length; four left and three right marginal rows; invariably three complete dorsal kineties; many macronuclear nodules; one contractile vacuole above mid-body of cell.

SSU rRNA gene sequence. The SSU rRNA gene sequence, which has a length of $1690 \mathrm{bp}$, was deposited in GenBank/ EMBL/DDBJ with the accession number FJ775718.

Type locality. Shenzhen Mangrove Nature Protection Area, South China Sea (Shenzhen, $22^{\circ} 37^{\prime} \mathrm{N} 114^{\circ} 04^{\prime} \mathrm{E}$ ), China.

Type slides. One holotype slide (registration no. WYG20080103011) and two paratype slides (registration nos WYG-20080103012 and WYG-20080103013) with protargolimpregnated specimens have been deposited in the Laboratory of Protozoology, Ocean University of China. A third paratype slide has been deposited in the Natural History Museum, UK, with registration no. NHMUK 2010:5:7:1.

Etymology. The species-group name flavicana is the composite of flavus - $a-u m$ (yellow) and canus - $a-u m$ (white) and alludes to the colour of the cell when viewed at high magnification.

Description. Cell in vivo about $130-200 \times 30-60 \mu \mathrm{m}$, body flexible and slightly contractile, elongate and somewhat sigmoid, right and left margins slightly convex, ratio of length to width about 3.5-5:1, dorsoventrally flattened about $2: 1$ (Figs $1 \mathrm{a}, \mathrm{b}$ and $2 \mathrm{a}, \mathrm{g}, \mathrm{h}$ ). Buccal cavity wedgeshaped, about $35 \%$ of body length (Figs 1a and $2 a$ ).

Body colour appears dark reddish at low magnification but yellowish at high magnification (Fig. 2a, g, h). Brightyellow cortical granules $(1 \mu \mathrm{m}$ in diameter), some grouped around the ventral cirri and dorsal cilia, others arranged in lines between the ventral cirral rows and the dorsal ciliary rows (Figs $1 \mathrm{c}$, d and $2 \mathrm{~b}-\mathrm{f}$ ). Cytoplasm colourless, usually with many tiny lipid droplets (about $1-3 \mu \mathrm{m}$ across) and food vacuoles containing diatoms.

Contractile vacuole about $10 \mu \mathrm{m}$ across, located anterior of mid-body, near left margin (Fig. 1a, b). Macronuclear nodules varying in shape from broad- to elongateellipsoidal, 4-12 $\mu \mathrm{m}$ long, scattered within body and difficult to recognize in vivo (Fig. $1 \mathrm{~g}$ ).

Locomotion by crawling moderately quickly on debris. 

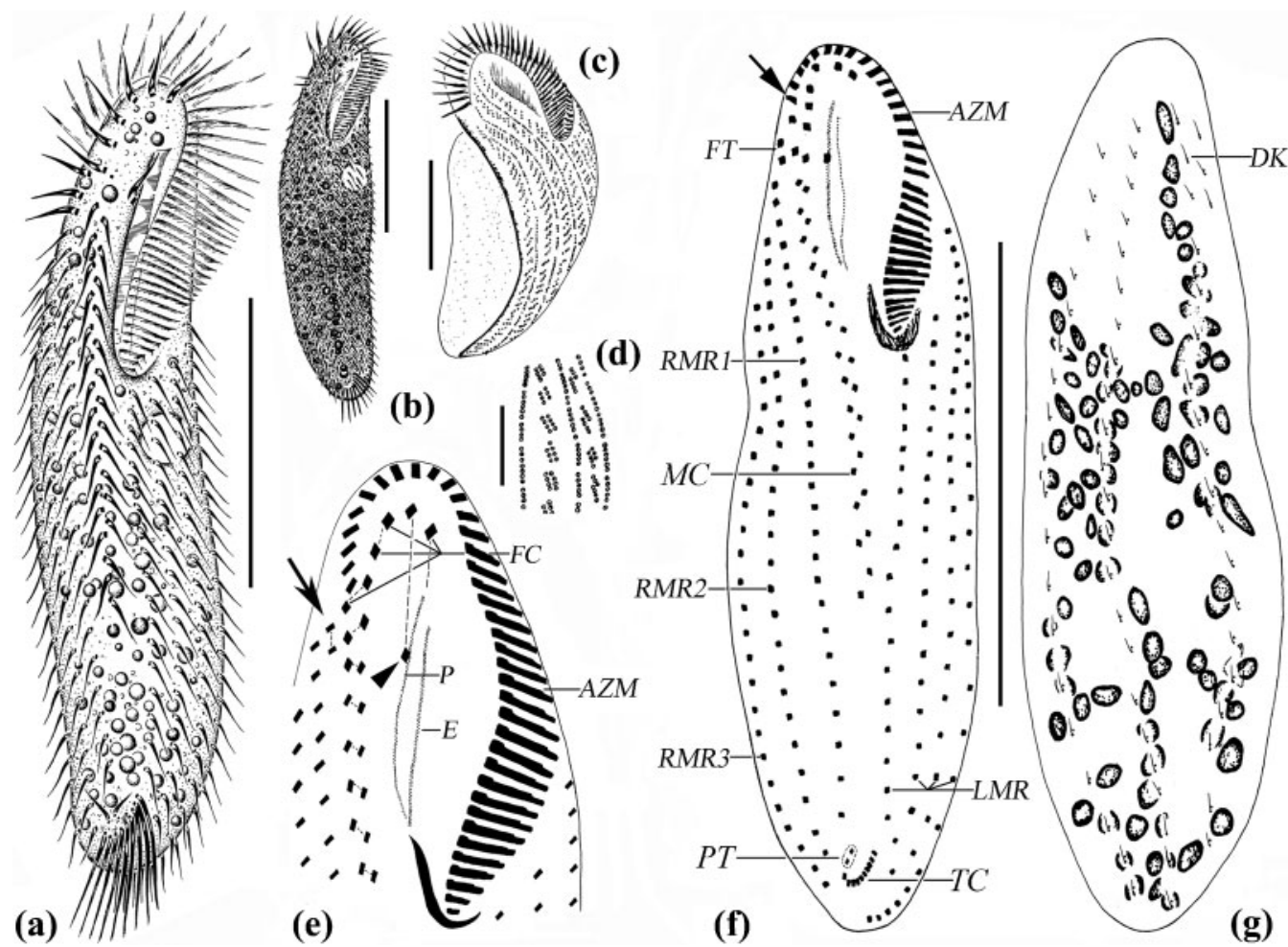

Fig. 1. Metaurostylopsis flavicana observed in vivo $(a-d)$ and after protargol impregnation (e-g). (a) Ventral view of a representative individual showing sigmoid body outline. (b) Ventral view of an individual with convex right margin and left margin almost straight. (c) Cortical granules on ventral side. (d) Dorsal side, showing cortical granules. (e) Ventral ciliature of anterior portion of cell. Arrow shows frontoterminal cirri; arrowhead marks buccal cirrus. Cirri originating from the same frontal-midventraltransverse cirral anlage are connected by broken lines. $(f, g)$ Ventral $(f)$ and dorsal $(g)$ views of the same individual, showing infraciliature and nuclear apparatus. Arrow indicates the distal end of AZM. AZM, Adoral zone of membranelles; DK, dorsal kinety; $\mathrm{E}$, endoral; FC, frontal cirri; FT, frontoterminal cirri; LMR, left marginal row; MC, midventral complex; P, paroral; PT, pretransverse ventral cirri; RMR1-3, right marginal rows 1-3; TC, transverse cirri. Bars, $50 \mu \mathrm{m}(\mathrm{a}-\mathrm{c}), 10 \mu \mathrm{m}(\mathrm{d})$ and $80 \mu \mathrm{m}(\mathrm{f}, \mathrm{g})$.

AZM composed of about 40 membranelles, cilia of membranelles about $15 \mu \mathrm{m}$ long in vivo. Proximal end of AZM terminates at about upper one-third of body (Figs if and $2 \mathrm{j}$ ), distal end of AZM bent only slightly towards the right (Figs 1e and 2j; Fig. 1f, arrow; Fig. 2i, double arrowhead). Paroral and endoral almost parallel and equal in length ( $\mathrm{P}$ and $\mathrm{E}$; Figs 1e and 2i). Pharyngeal fibres conspicuous after protargol impregnation.

All cirri relatively fine, mostly $8-10 \mu \mathrm{m}$ long, frontal and transverse cirri about $13 \mu \mathrm{m}$ long. Four to eight clearly differentiated frontal cirri that are continuous with midventral complex (FC; Figs 1e and 2i). Midventral complex composed of 13-17 pairs of cirri in a zigzag pattern, about $60 \%$ of cell length (Figs $1 \mathrm{e}, \mathrm{f}$ and $2 \mathrm{j}$ ). Two frontoterminal cirri near distal end of AZM (FT; Fig. 1e, arrow; Figs if and 2j). Single buccal cirrus located at level of anterior one-third of the paroral (Figs 1e and 2i, arrowhead; Fig. 1f). Seven to ten transverse cirri projecting beyond posterior body margin, arranged in a J-shaped row in gap between marginal cirral rows (TC; Figs $1 f$ and $2 \mathrm{j}$ ). Two pretransverse ventral cirri (PT; Figs if and 2j).
Invariably four left and three right marginal rows (LMR and RMR; Figs 1a, f and 2j). On dorsal side, three complete kineties plus one short row anterior of rightmost marginal row, usually with three pairs of basal bodies (DK; Fig. 1g).

Morphogenesis. One specimen was observed at a middle stage of morphogenesis. The oral apparatus and new cirri are completely formed in both proter and opisthe. One cirrus from the undulating membranes anlagen migrates anteriorly to become the leftmost frontal cirrus (Fig. 2k, arrow). At the same time, one cirrus from the frontomidventral transverse cirral anlage II moves posteriorly to become the buccal cirrus (Fig. $2 \mathrm{k}$, arrowhead). Several posterior cirral anlagen contribute one transverse cirrus each, and the pretransverse ventral cirri (encircled by broken line in Fig. 2l) come from the two posteriormost cirral anlagen.

\section{Comparison}

Hitherto, six species of Metaurostylopsis have been reported, namely M. marina (Kahl, 1932) Song et al., 

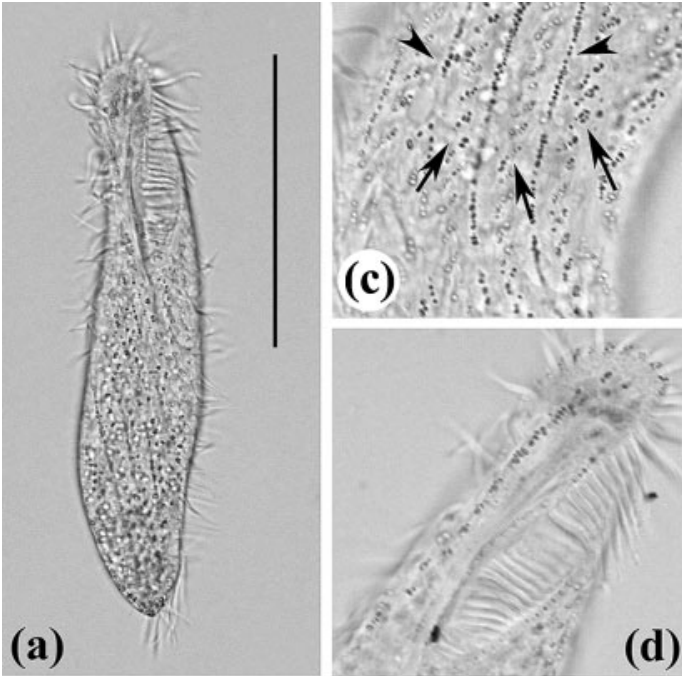

(a)

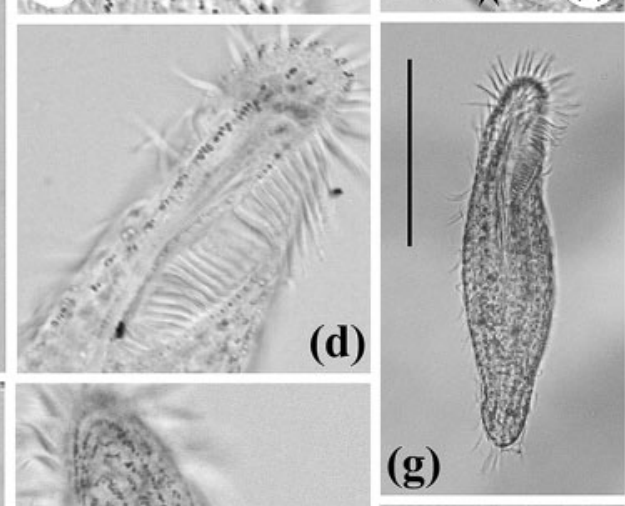

(b)

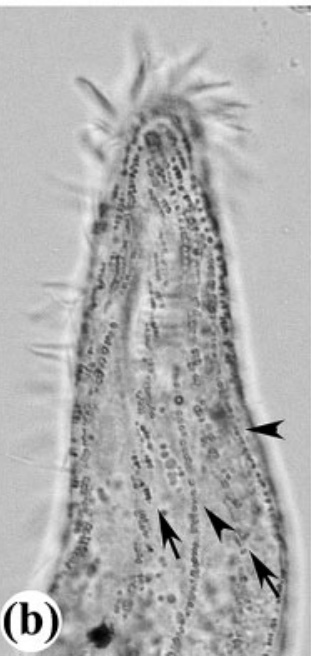

(h)

(e)
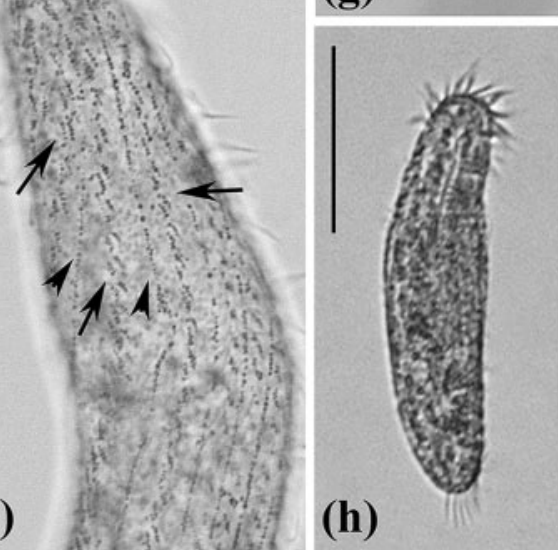
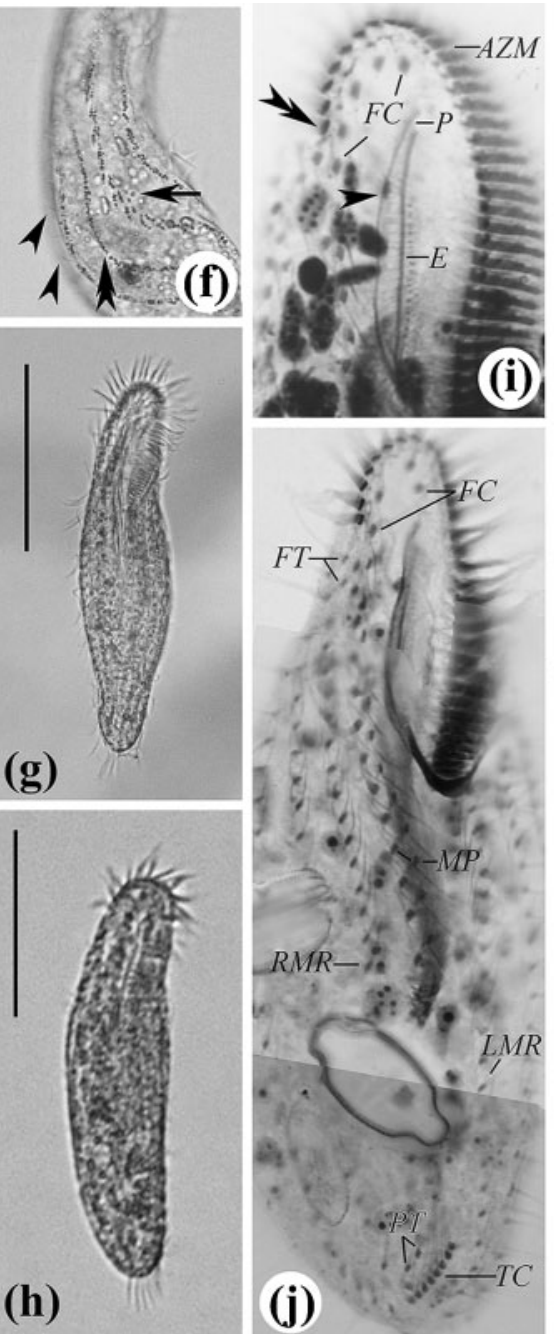

(j)

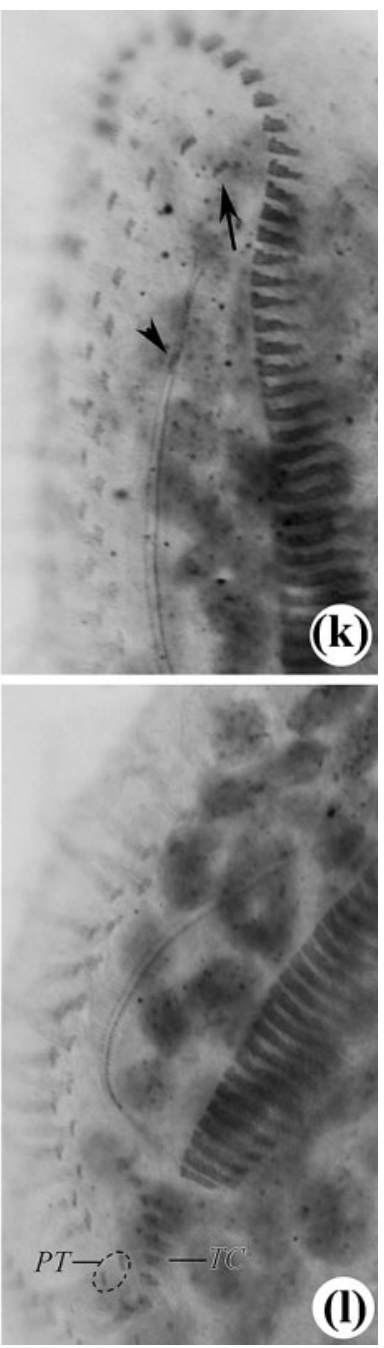

Fig. 2. Photomicrographs of Metaurostylopsis flavicana from life (a-h) and after protargol impregnation (i-l). (a) Ventral view of a representative specimen. (b, e, f) Arrangement of cortical granules on dorsal side. Arrows show cortical granules grouped around dorsal bristles; arrowheads in (b) and (e) and double arrowhead in (f) point to cortical granules aligned between dorsal kineties; arrowheads in (f) mark dorsal bristles. (c) Ventral view, showing cortical granules grouped around cirri (arrows) and cortical granules aligned between cirral rows (arrowheads). (d) Ventral view of anterior portion of cell showing cortical granules around cirri. $(\mathrm{g}, \mathrm{h}$ ) Different cells showing flexible body. (i) Anterior portion of cell showing ventral ciliature. Arrowhead shows buccal cirrus, double arrowhead marks the distal end of AZM. (j) Ventral view showing infraciliature. (k) Ventral view of anterior portion of proter. Arrow and arrowhead show the newly formed leftmost frontal and buccal cirri, respectively. (I) Ventral view of portion of opisthe; two new pretransverse ventral cirri are encircled by broken line. MP, Midventral pair; see Fig. 1 for other abbreviations. Bars, $90 \mu \mathrm{m}(\mathrm{a})$ and $50 \mu \mathrm{m}(\mathrm{g}, \mathrm{h})$.

2001, M. rubra Song \& Wilbert, 2002, M. songi Lei et al., 2005, M. salina Lei et al., 2005, M. struederkypkeae Shao et al., 2008 and M. sinica Shao et al., 2008 (Table 2).

Compared with M. marina, the type species, M. flavicana, has an elongate elliptical (vs oval) body outline, dark reddish to yellowish (vs colourless to greyish) cell colour and bright yellow (vs colourless to greenish) cortical granules, lacks a midventral row (vs midventral row present in M. marina) and has fewer (two vs three to six) frontoterminal cirri (Song et al., 2001).
M. flavicana differs from $M$. rubra in having fewer frontoterminal cirri (two vs five to eight), fewer left (four vs six to nine) and right (three vs six or seven) marginal rows and the absence (vs presence) of a midventral row (Song \& Wilbert, 2002).

M. songi resembles M. flavicana in body size and shape and some features of the infraciliature, but can be distinguished from the latter by its cell colour (colourless vs yellowish) and arrangement of the cortical granules. Additionally, M. songi has three (vs four) left marginal rows (Lei et al., 2005). 


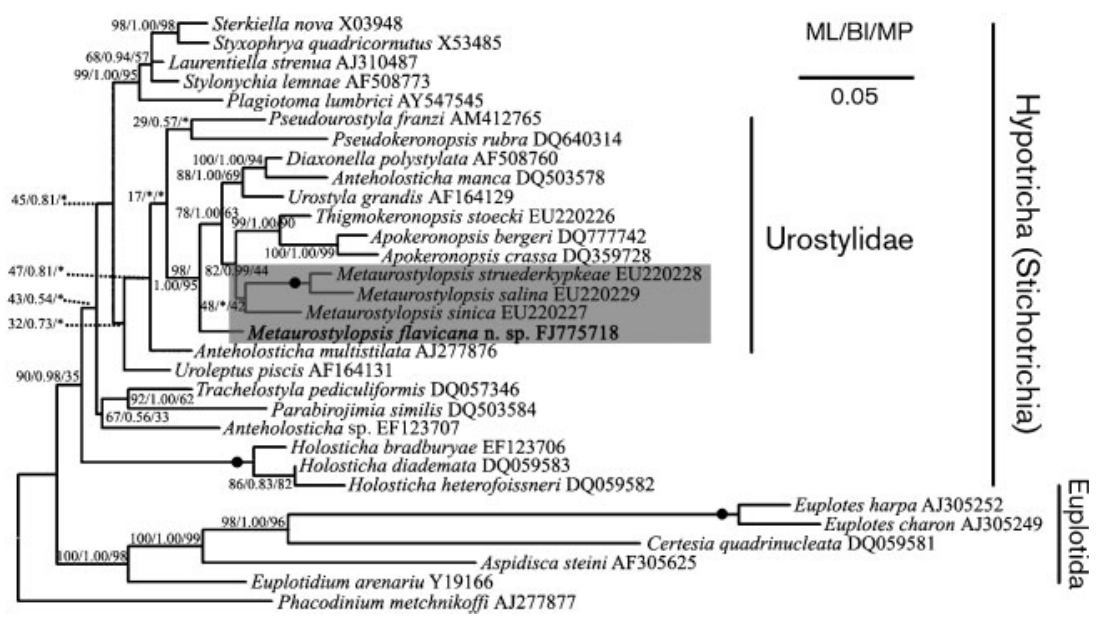

Fig. 3. $M L$ tree inferred from SSU rRNA gene sequences showing the position of Metaurostylopsis species. Asterisks denote clades with different topologies in the $\mathrm{BI}$ and MP trees. Numbers at nodes are bootstrap values of the $M L$ analysis, posterior probabilities from the $\mathrm{Bl}$ analysis and MP bootstrap values, respectively. Species of Metaurostylopsis are shown against a shaded box. Black dots on nodes indicate maximal $(100 \% \mathrm{ML}, 1.00 \mathrm{BI}$, $100 \%$ MP) support in all analyses. Taxonomic classification follows Lynn (2008). Bar, 5 substitutions per 100 nucleotide positions.

M. salina is separated from M. flavicana by its pyriform (vs elongate and sigmoidal) body shape and in having fewer adoral membranelles (18-25 vs 33-45) and midventral cirral pairs (4-7 vs 13-17) and more (three to five vs two) frontoterminal cirri (Lei et al., 2005; Shao et al., 2008a). In addition, the divergence of these two forms is supported by SSU rRNA gene sequence data, as they differ in $101 \mathrm{nt}$ (structural similarity $94.2 \%$ ).

M. struederkypkeae differs from $M$. flavicana in having fewer adoral membranelles (20-25 vs 33-45) and midventral cirral pairs (4-7 vs 13-17) and more frontoterminal cirri (four to six vs two), a midventral row (vs absent in $M$. flavicana) and two kinds (vs only one kind) of cortical granules (Shao et al., 2008b). The separation of these two taxa is also firmly supported by molecular data, which show a significant discrepancy in their SSU rRNA gene sequences (structural similarity $94.6 \%$ ).

M. sinica differs from M. flavicana in having two kinds (vs only one kind) of cortical granules, fewer marginal rows (three left and two right vs four left and three right) and a long midventral complex that extends to the posterior end (vs terminates at posterior two-fifths) of the cell (Shao et al., 2008a). The divergence of these two forms is also supported by SSU rRNA gene sequence data, as they differ in 73 nt (structural similarity $95.8 \%$ ).

\section{Systematic position of $\boldsymbol{M}$. flavicana}

Based on its ciliature, $M$. flavicana clearly belongs to the genus Metaurostylopsis, i.e. it has clearly differentiated frontal, frontoterminal, buccal and transverse cirri, a midventral complex, more than one row of marginal cirri on each side and lacks caudal cirri (Song et al., 2001). However, such generic assignment for this species seems not to be supported by SSU rRNA gene nucleotide sequence data. As shown in Fig. 3, M. salina, M. struederkypkeae and M. sinica group first, with low support, and then form a clade with Apokeronopsis and Thigmokeronopsis, whereas M. flavicana branches separately, suggesting that the genus Metaurostylopsis may be paraphyletic. This difference could be explained as follows: on the one hand, considering their conspicuous morphological diversity, i.e. cell outline and colour, types and colour of cortical granules, numbers of adoral membranelles, frontoterminal cirri and midventral cirral pairs as well as marginal rows and the presence or absence of a midventral row (Lei et al., 2005; Berger 2006; Shao et al., 2008a, b), members of Metaurostylopsis possibly evolved several times independently; on the other, limited sequence data and phylogenetic analyses based only on the SSU rRNA gene sequence may not resolve the taxonomy of the genus Metaurostylopsis.

The SSU rRNA gene sequence data show that Metaurostylopsis belongs to the family Urostylidae, where it forms a strongly supported clade with Diaxonella, Urostyla, Thigmokeronopsis and Apokeronopsis (Fig. 3). This placement is consistent with the morphological data, which also suggest that Metaurostylopsis is a urostylid, as defined by Berger (2006) and Lynn (2008).

\section{Tunicothrix wilberti (Lin \& Song, 2004) Xu et al., 2006 (Figs 4 and 5; Table 1)}

Prior to the current investigation, this species had never been recorded from mangrove habitats to the best of our knowledge. Moreover, it has only been reported once, so a redescription is necessary in order to understand its intraspecific variation. Based on both previous and present studies, an improved diagnosis is supplied.

Improved diagnosis. Size in vivo about $80-180 \times 15$ $70 \mu \mathrm{m}$; body elongate; usually two macronuclear nodules and one to four micronuclei; $7-12$ (8-12 according to Lin \& Song, 2004) distal and 16-20 proximal membranelles; three frontal, one parabuccal and one buccal, one pretransverse ventral and two to five transverse cirri; usually one, rarely two, midventral pairs and a midventral row of 15-36 cirri; $21-36$ cirri in left marginal row, 25-47 in the inner right marginal row and $18-39$ in the outer right marginal row, which is shortened anteriorly and located ventrally; invariably three complete dorsal kineties. 
Table 1. Morphometric characterization of M. flavicana spec. nov. and T. wilberti

Data are based on protargol-impregnated specimens. -, Data not available/not applicable; $n$, number.

\begin{tabular}{|c|c|c|c|c|c|c|}
\hline Character & Species & Min. & Max. & Mean & SD & $n$ \\
\hline \multirow[t]{2}{*}{ Body length $(\mu \mathrm{m})$} & M. flavicana & 135 & 195 & 159.1 & 16.77 & 8 \\
\hline & T. wilberti & 82 & 111 & 96.6 & 7.70 & 25 \\
\hline Body width $(\mu \mathrm{m})$ & T. wilberti & 18 & 40 & 24.4 & 4.92 & 25 \\
\hline \multirow[t]{2}{*}{ Buccal field, length ( $\mu \mathrm{m})$} & M. flavicana & 50 & 67 & 57.6 & 5.92 & 8 \\
\hline & T. wilberti & 22 & 37 & 29.1 & 3.41 & 25 \\
\hline Adoral membranelles $(n)$ & T. wilberti & - & - & - & - & - \\
\hline \multirow[t]{2}{*}{ Distal membranelles $(n)$} & M. flavicana & - & - & - & - & - \\
\hline & T. wilberti & 7 & 11 & 9.2 & 0.95 & 20 \\
\hline \multirow[t]{2}{*}{ Proximal membranelles $(n)$} & M. flavicana & - & - & - & - & - \\
\hline & T. wilberti & 16 & 20 & 18.2 & 1.09 & 20 \\
\hline Buccal cirri $(n)$ & M. flavicana & 1 & 1 & 1 & 0 & 9 \\
\hline Frontoterminal cirri $(n)$ & T. wilberti & - & - & - & - & - \\
\hline \multirow[t]{2}{*}{ Midventral pairs $(n)$} & M. flavicana & 13 & 17 & 14.3 & 1.14 & 12 \\
\hline & T. wilberti & - & - & - & - & - \\
\hline \multirow{2}{*}{ Cirri in midventral row $(n)$} & M. flavicana & - & - & - & - & - \\
\hline & T. wilberti & 15 & 23 & 19.7 & 2.23 & 20 \\
\hline \multirow[t]{2}{*}{ Left marginal rows $(n)$} & M. flavicana & 4 & 4 & 4 & 0 & 15 \\
\hline & T. wilberti & 1 & 1 & 1 & 0 & 20 \\
\hline \multirow[t]{2}{*}{ Cirri in left marginal row $1(n)$} & M. flavicana & 19 & 29 & 22.1 & 3.43 & 11 \\
\hline & T. wilberti & 24 & 35 & 28.9 & 2.89 & 20 \\
\hline \multirow[t]{2}{*}{ Cirri in left marginal row $2(n)$} & M. flavicana & 17 & 26 & 21.5 & 4.03 & 11 \\
\hline & T. wilberti & - & - & - & - & - \\
\hline Cirri in right marginal row $1(n)$ & T. wilberti & 25 & 38 & 31.6 & 3.53 & 20 \\
\hline \multirow[t]{2}{*}{ Cirri in right marginal row $2(n)$} & M. flavicana & 26 & 37 & 31.3 & 3.50 & 11 \\
\hline & T. wilberti & 26 & 37 & 32.1 & 2.85 & 19 \\
\hline \multirow[t]{2}{*}{ Cirri in right marginal row $3(n)$} & M. flavicana & 24 & 34 & 28.8 & 4.07 & 10 \\
\hline & T. wilberti & - & - & - & - & - \\
\hline \multirow[t]{2}{*}{ Pretransverse ventral cirri $(n)$} & M. flavicana & 2 & 2 & 2 & 0 & 15 \\
\hline & T. wilberti & 1 & 1 & 1 & 0 & 20 \\
\hline Transverse cirri $(n)$ & M. flavicana & 7 & 10 & 8.8 & 1.06 & 12 \\
\hline & T. wilberti & 4 & 4 & 4 & 0 & 19 \\
\hline Dorsal kineties $(n)$ & M. flavicana & 3 & 3 & 3 & 0 & 15 \\
\hline & T. wilberti & 3 & 3 & 3 & 0 & 23 \\
\hline Macronuclear nodules $(n)$ & M. flavicana & 62 & 97 & 75.3 & 10.84 & 9 \\
\hline & T. wilberti & 1 & 2 & 2 & 0.22 & 20 \\
\hline
\end{tabular}

${ }^{\star}$ Including one parabuccal cirrus and two or four cirri in midventral pairs.

Description. Body usually $90-120 \times 15-30 \mu \mathrm{m}$ in vivo, elongate with length: width ratio about $3-4: 1$; both ends rounded, anterior end wider than posterior (Fig. $4 \mathrm{a}, \mathrm{b}$ ).
Body flexible but non-contractile (Fig. 4c). Hyaline alveolar layer, 3-4 $\mu \mathrm{m}$ thick, covers the cell, making cortex visible even at low magnification. Buccal field narrow, about 
Table 2. Morphometric comparison of M. flavicana spec. nov. with its congeners

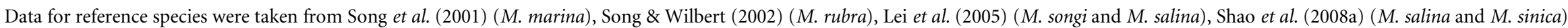
and Shao et al. (2008b) (M. struederkypkeae). NA, No data available.

\begin{tabular}{|c|c|c|c|c|c|c|c|c|}
\hline \multirow[t]{2}{*}{ Character } & \multirow[t]{2}{*}{ M. marina } & \multirow[t]{2}{*}{ M. rubra } & \multirow[t]{2}{*}{ M. songi } & \multicolumn{2}{|c|}{ M. salina } & \multirow[t]{2}{*}{ M. struederkypkeae } & \multirow[t]{2}{*}{ M. sinica } & \multirow[t]{2}{*}{ M. flavicana } \\
\hline & & & & Lei et al. (2005) & Shao et al. (2008a) & & & \\
\hline Body size in vivo $(\mu \mathrm{m})$ & $80-120 \times 50-80$ & $150-300 \times 50-90$ & $90-150 \times 20-35$ & $40-80 \times 15-30$ & $70-120 \times 20-30$ & $90-120 \times 20-30$ & $100-120 \times 25-35$ & $130-200 \times 30-60$ \\
\hline Body colour & $\begin{array}{l}\text { Colourless to } \\
\text { greyish }\end{array}$ & Brick-reddish & $\mathrm{NA}$ & Somewhat russet & $\begin{array}{l}\text { Colourless to } \\
\text { greyish }\end{array}$ & Rose-reddish & Yellow-brownish & $\begin{array}{c}\text { Reddish to } \\
\text { yellowish }\end{array}$ \\
\hline Body outline & Oval & Elongate & Slender elliptical & Pyriform & Pyriform & Slender & Elongate elliptical & $\begin{array}{c}\text { Elongate } \\
\text { elliptical }\end{array}$ \\
\hline Cortical granules, colour & Colourless & $\mathrm{NA}$ & Colourless & Colourless & Colourless & $\begin{array}{l}\text { Type I, yellow-green; } \\
\text { type II, wine-reddish }\end{array}$ & $\begin{array}{l}\text { Type I, yellow; } \\
\text { type II, colourless }\end{array}$ & Bright yellow \\
\hline Buccal field length/body length & $40 \%$ & $\sim 30 \%$ & $25-33 \%$ & $38 \%$ & $35 \%$ & $30 \%$ & $30-35 \%$ & $33 \%$ \\
\hline Position of contractile vacuole & $\begin{array}{l}\text { Equatorial } \\
\text { level }\end{array}$ & Equatorial level & $\begin{array}{l}\text { Anterior of } \\
\text { mid-body }\end{array}$ & Equatorial level & Anterior $2 / 5$ & Anterior $2 / 5$ & Anterior $2 / 5$ & $\begin{array}{l}\text { Anterior of mid- } \\
\text { body }\end{array}$ \\
\hline Adoral membranelles $(n)$ & $22-30$ & $35-46$ & $28-47$ & $18-23$ & $21-25$ & $20-25$ & $25-29$ & $33-45$ \\
\hline Frontal cirri $(n)$ & 4 & 4 & 5 & $3^{*}$ & 4 & 4 & 4 & $4-8$ \\
\hline Frontoterminal cirri $(n)$ & $3-6$ & $5-8$ & $2-3$ & $3-5$ & $4-5$ & $4-6$ & 2 & 2 \\
\hline Midventral pairs $(n)$ & $7-11 \dagger$ & $8-11 \dagger$ & $9-12$ & $4-5$ & $6-7$ & $4-7$ & $11-15$ & $13-17$ \\
\hline Midventral row & Present & Present & Absent & Present & Present & Present & Absent & Absent \\
\hline Left marginal rows $(n)$ & $3-5$ & 6-9 & 3 & 3 & $2-4$ & $4-5$ & 3 & 4 \\
\hline Right marginal rows $(n)$ & $3-5$ & $6-7$ & 3 & 3 & 3 & 3 & 2 & 3 \\
\hline Transverse cirri $(n)$ & $5-9$ & $4-6$ & $6-7$ & $2-5$ & $3-5$ & $2-5$ & $5-8$ & $7-10$ \\
\hline Dorsal kineties $(n)$ & $3-5$ & 3 & 3 & 3 & 3 & 3 & 3 & 3 \\
\hline
\end{tabular}

${ }^{*}$ Misinterpreted; should be four in the opinion of Shao et al. (2008a).

$\dagger$ Not including cirri in midventral row. 

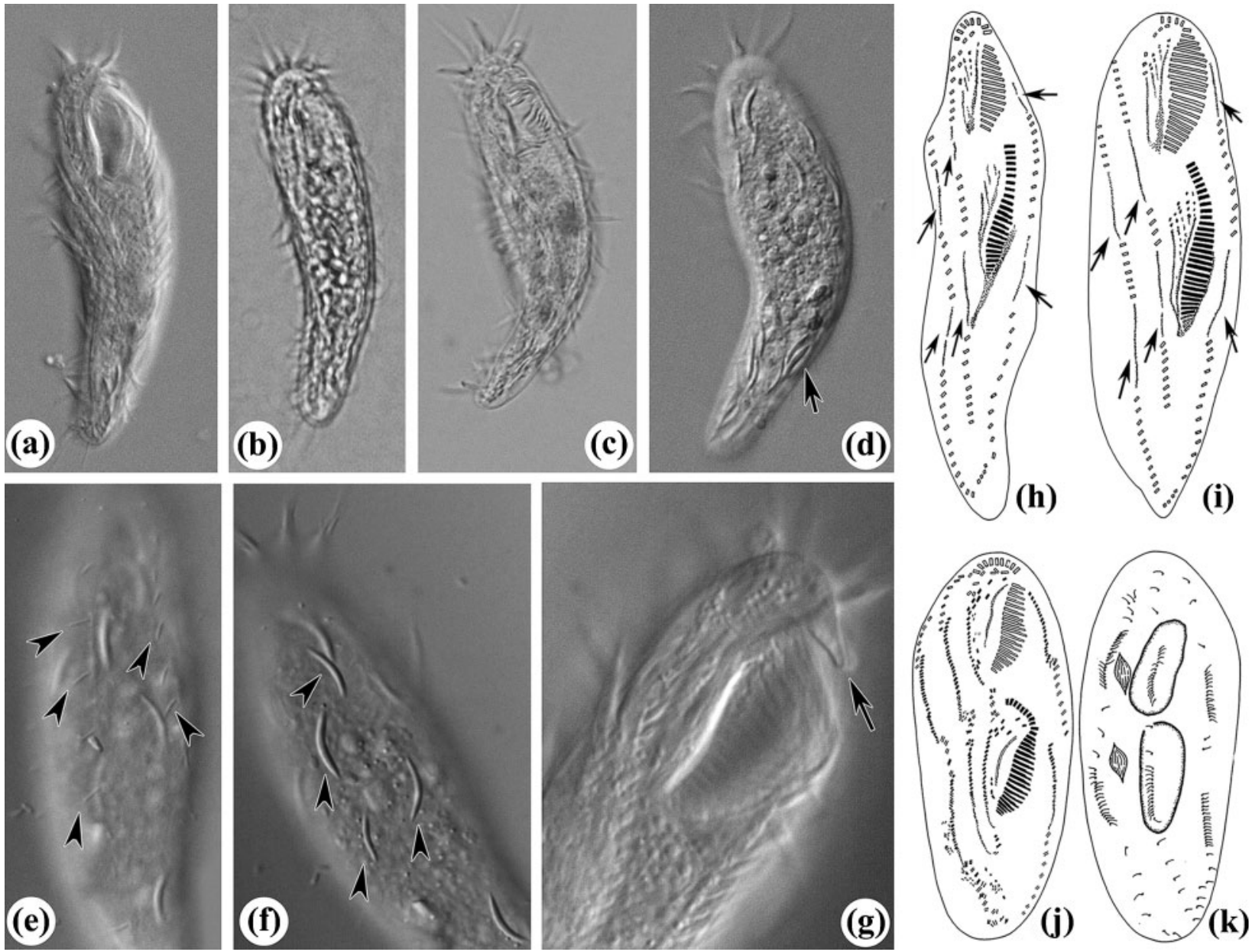

Fig. 4. Tunicothrix wilberti observed in vivo $(\mathrm{a}-\mathrm{g})$ and after protargol impregnation $(\mathrm{h}-\mathrm{k})[(\mathrm{a}-\mathrm{i})$, original; ( $\mathrm{j}$, $\mathrm{k})$ reproduced with permission from Lin \& Song (2004)]. (a-c) Ventral views of different cells, showing body shape and hyaline alveolar layer. (d) Dorsal view showing the arc-shaped cortical structure (arrow). (e, f) Dorsal views of portions of the cell. Arrowheads in (e) and (f) show dorsal bristles and the arc-shaped cortical structures, respectively. (g) Ventral view of anterior portion of cell showing beak-like frontal protrusion (arrow). ( $h$, i) Ventral views of early mid-stage ( $h$ ) and mid-stage (i) dividers, showing development of the opisthe's oral primordium, frontal-midventral-transverse cirral anlagen and formation of two anlagen within each parental marginal row (arrows). (j, k) Late-stage divider; ventral (j) and dorsal (k) views of the same cell showing cirral formation and further development of oral primordium and dorsal kineties anlagen.

one-third of body length (Fig. 4a, c); a beak-like protrusion conspicuous in the anterior-left of it (Fig. 4g, arrow). Pellicle semi-rigid, no typical cortical granules observed, but on dorsal side and posterior region of ventral side is a scattering of colourless arc-shaped structures about 7$8 \mu \mathrm{m}$ long (Fig. 4d, arrow; Fig. 4f, arrowheads). Cytoplasm colourless to greyish, with many conspicuous globules of various sizes (3-10 $\mu \mathrm{m}$ across) and food vacuoles containing diatoms. Contractile vacuole not observed. Usually two (rarely one) ovoid to ellipsoid macronuclear nodules, lying in mid-body (Fig. 5a, c; Fig. 5k, arrowhead) and one to four micronuclei (Fig. 5c, k, arrows; Fig. 5f).

Locomotion relatively fast, crawling on the bottom of the Petri dish or on debris, with short, frequent pauses and changes of direction.
AZM bipartite with a conspicuous gap between distal and proximal portions (Fig. 5a, double arrowhead). Distal part composed of 7 to 11 membranelles, with cilia about $15 \mu \mathrm{m}$ long. Proximal part composed of 16-20 membranelles. Paroral and endoral almost equal in length, intersecting in anterior region (Fig. 5c, d, l, arrow and arrowhead; Fig. 5g, arrowhead). Invariably three frontal cirri (Fig. 5f, i, arrowheads) with cilia about $12-15 \mu \mathrm{m}$ long; single buccal cirrus situated near mid-region of the paroral (Fig. 5c, g, arrow); one parabuccal cirrus beside the rightmost frontal cirrus (Fig. 5c, arrowheads; Fig. 5f, i, arrows). Usually one (rarely two) pair of midventral cirri (Fig. 5c, f, i) lying close to anterior end of midventral row which comprises 15-23 cirri and terminates in posterior twofifths of body (Fig. 5a, e, arrow). One pretransverse ventral 

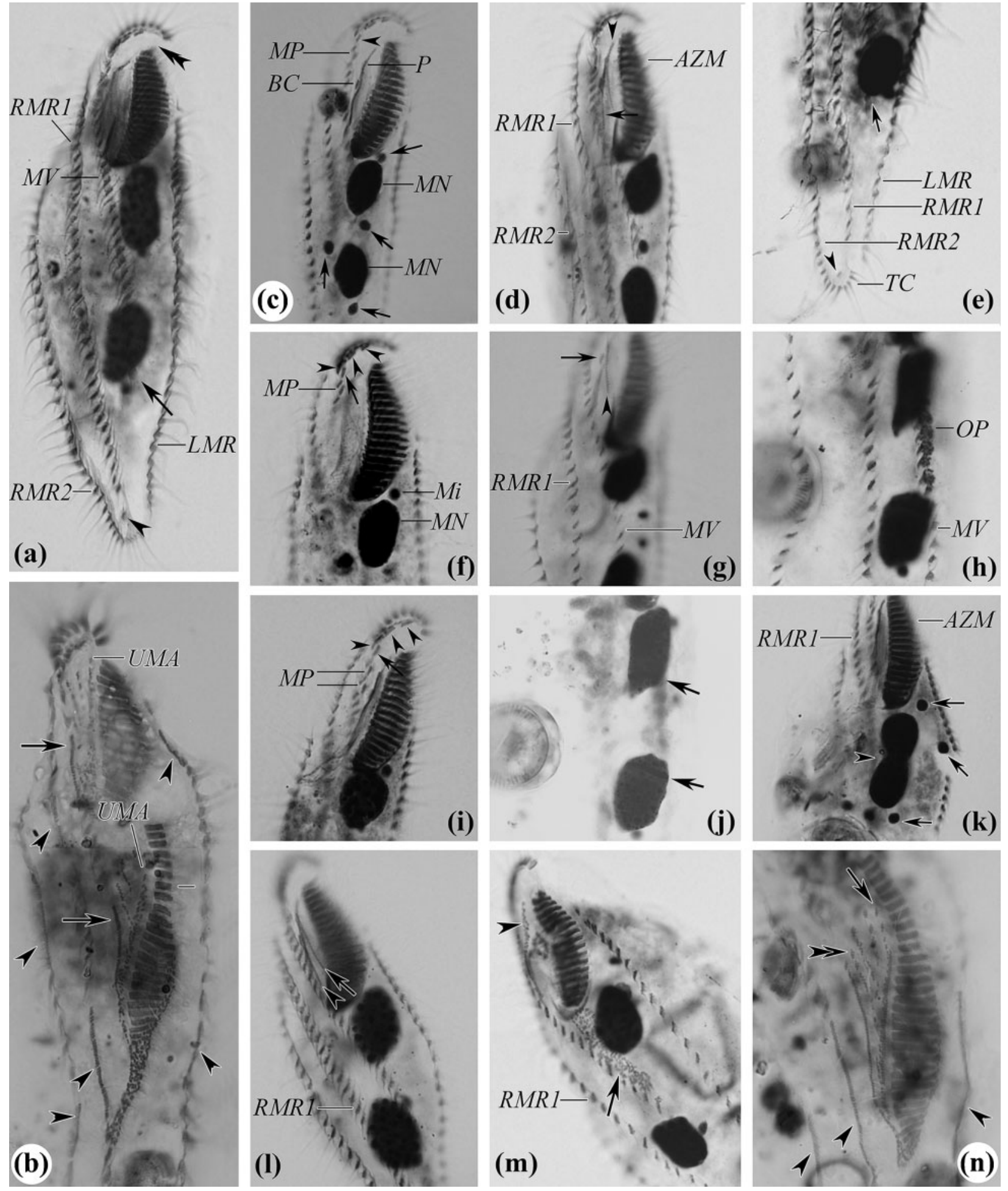

Fig. 5. Photomicrographs of Tunicothrix wilberti after protargol impregnation. (a) Ventral view of a typical specimen showing infraciliature. Arrow marks the midventral row terminating at posterior one-third; double arrowhead indicates gap between two portions of AZM; arrowhead denotes pretransverse ventral cirrus. (b) Ventral view of an early mid-stage divider, showing development of marginal cirral anlagen within old structures (arrowheads) and the opisthe's oral primordium and frontalmidventral-transverse cirral anlagen in both the proter and the opisthe (arrows). (c) Anterior portion of cell (ventral view) showing the buccal apparatus, macronuclear nodules and micronuclei (arrows); arrowhead indicates the parabuccal cirrus. (d) Anterior portion of cell (ventral view) showing the paroral (arrowhead) and endoral (arrow). (e) Posterior portion of cell (ventral view) showing the termination of the midventral row (arrow) and the pretransverse ventral cirrus (arrowhead). ( $f$ ) Anterior portion of cell 
(ventral view) showing frontal cirri (arrowheads), parabuccal cirrus (arrow) and one midventral pair. (g) Portion of cell (ventral view) showing the paroral (arrowhead) and buccal cirrus (arrow). ( $h, j$ ) Ventral view of an early divider showing the appearance of the opisthe's oral primordium near the midventral cirri and macronuclear replication bands (arrows). (i) Anterior portion of cell (ventral view) showing frontal cirri (arrowheads), parabuccal cirrus (arrow) and two midventral pairs. (k) Ventral view of an individual with a dumb-bell-shaped macronucleus (arrowhead) and micronuclei (arrows). (l) Ventral view showing the paroral (arrow) and endoral (arrowhead). (m) Ventral view of an early reorganizer showing the appearance of the oral primordium (arrow) and the dedifferentiation of the paroral at its anterior end (arrowhead). ( $n$ ) Middle-stage divider (ventral view) showing the marginal row anlagen within old structures (arrowheads) and segmentation of frontal-midventral-transverse cirral anlagen II-V (double arrowhead) and undulating membranes anlage (arrow). BC, Buccal cirrus; LMR, left marginal row; Mi, micronucleus; $\mathrm{MN}$, macronuclear nodule; MP, midventral pair; MV, midventral row; OP, oral primordium; $\mathrm{P}$, paroral; RMR1, 2, right marginal rows 1 and 2; TC, transverse cirri; UMA, undulating membranes anlage. See Fig. 1 for other definitions.

cirrus (Fig. 5a, e, arrowhead) and four transverse cirri (Fig. $5 e)$, cilia of which are fine, about $12-15 \mu \mathrm{m}$ long, and lie close to posterior end of outer right marginal row. One left and two right marginal rows; left row composed of 24-35 cirri; inner right marginal row composed of 25-38 cirri and terminates subcaudally; outer right marginal row composed of 26-37 cirri and extends almost to posterior end of cell (Fig. $5 \mathrm{a}, \mathrm{e})$, with cilia of marginal cirri about $10 \mu \mathrm{m}$ long in vivo.

Dorsal cilia bristle-like (Fig. 4e, arrowheads), about 3$5 \mu \mathrm{m}$ long, arranged in three rows that extend over entire length of body.

\section{Comparison}

The mangrove population of $T$. wilberti corresponds well in its general morphology in vivo and infraciliature with the original population, thus supporting their conspecificity (Lin \& Song, 2004). The main difference is that the former possesses a beak-like frontal protrusion, which was not described by Lin \& Song (2004). Nevertheless, one of the photomicrographs in the original report (Fig. 17 of Lin \& Song, 2004) seems to show traces of such a structure in a stained specimen, suggesting that it was present. Another difference between the two populations is the distribution of the arc-shaped cortical structures which, in the original population, are arranged in three rows on the dorsal side whereas, in the current population, they are scattered on the dorsal side and the posterior region of the ventral side. This is not, however, considered a sufficiently reliable character for species separation.

Compared with $T$. rostrata, the type species, $T$. wilberti has a shortened right marginal row 2 on the ventral side (vs elongated and curving onto the dorsal side anteriorly), fewer distal (7-12 vs $14-18$ ) and proximal (16-20 vs $23-$ 28) membranelles, less-differentiated frontal cirri (i.e. similar to midventral cirri vs distinctly differentiated), fewer cirri (18-39 vs 53-66) in right marginal row 2 and usually only one (vs two) midventral pair (Xu et al., 2006).

\section{Morphogenesis and reorganization (Figs $4 \mathrm{~h}-\mathrm{k}$ and $\mathbf{5 b}, \mathrm{h}, \mathrm{j}, \mathrm{m}, \mathrm{n}$ )}

Hitherto, knowledge of morphogenesis in Tunicothrix was confined to a report of a single specimen during the mid-stage of binary fission (Lin \& Song, 2004). In the current work, one regenerative and three divisional stages were observed (Fig. $4 \mathrm{~h}-\mathrm{k}$ and $\mathrm{5b}, \mathrm{h}, \mathrm{j}, \mathrm{m}, \mathrm{n})$. Based on these observations and those of Lin \& Song (2004), the following features can be deduced for $T$. wilberti. (i) Morphogenesis/reorganization commences with the apokinetal appearance of groups of closely spaced basal bodies, which is the oral primordium (Fig. 5h, OP; Fig. 4m, arrow), near the cirri in the midventral row. No cirri of the midventral row join in this process. (ii) Only five frontal-midventral-transverse cirral anlagen (including the anlagen for undulating membranes) are formed (Figs 4h-j; Fig. 5b, arrows; Fig. 5n, arrow and double arrowhead). (iii) During the formation of these anlagen, parabuccal, buccal and some midventral cirri become dedifferentiated. (iv) The anlagen for the marginal rows (Figs 3h, i, arrows; Fig. 4b, n, arrowheads) and dorsal kineties (Fig. 4k) arise within the parental structures. (v) In the opisthe, the frontal-midventral-transverse cirral anlagen and oral primordium connect posteriorly. (vi) In the proter, the parental AZM seems to be wholly retained, while the paroral becomes dedifferentiated (Fig. 5m, arrowhead). (vii) At an early stage, replication bands appear in macronuclear nodules (Fig. 5j, arrows).

\section{Systematic assignment of Tunicothrix}

In terms of morphology and morphogenesis, members of the genus Tunicothrix demonstrate several common urostylid features, e.g. a midventral complex comprising one to three midventral pairs and a midventral row, a simple dorsal kinety pattern consisting of three bipolar kineties and the 'within-structure proliferation' of the anlagen for the marginal rows and dorsal kineties. This suggests an evolutionary relationship between Tunicothrix and the urostylids. However, a few characters show discrepancies. For example: (i) in T. wilberti, only five frontal-midventral-transverse cirral anlagen are formed, and usually only one midventral pair is generated, whereas, in the urostylids, the ventral somatic ciliature develops from more than six cirral anlagen, resulting in the formation of at least two midventral pairs; (ii) T. wilberti has inconspicuously differentiated frontal cirri, similar to Parabirojimia (Hu et al., 2002; Chen et al., 2010a), whereas urostylids typically possess distinctly enlarged frontal cirri; and (iii) Tunicothrix usually has only one or two 
midventral pairs that lie next to the oral region, whereas in urostylids there are usually several midventral pairs forming a row that typically extends to the ventral region (Berger, 2006; Li et al., 2009; Chen et al., 2010b). Thus, the assignment of Tunicothrix to the family Urostylidae should be regarded as tentative and further data (e.g. SSU rRNA gene sequence) are required in order to ascertain its correct phylogenetic position.

\section{ACKNOWLEDGEMENTS}

Financial support was provided by the Natural Science Foundation of China (project no. 40976075) and a Marie Curie International Incoming Fellowship within the 7th European Community Framework Programme (to X. H.), the Royal Society Joint Projects programme (to W. Song and A. W.) and Research Group Project no. RGP-VPP-083, King Saud University Deanship of Scientific Research (to K. A.-R.). We would like to thank Ms Zhuo Shen, Mr Xinpeng Fan and Mr Weiwei Liu for their help with sampling, Dr Liqiong Li for drawing Fig. 1(a) and Dr Chen Shao and Ms Shan Gao for their critical reading of the manuscript.

\section{REFERENCES}

Berger, H. (2006). Monograph of the Urostyloidea (Ciliophora, Hypotricha). Monographiae Biologicae, vol. 85. Dordrecht: Springer.

Chen, X., Gao, S., Song, W., Al-Rasheid, K. A. S., Warren, A., Gong, J. \& Lin, X. (2010a). Parabirojimia multinucleata spec. nov. and Anteholosticha scutellum (Cohn, 1866) Berger, 2003, marine ciliates (Ciliophora, Hypotrichida) from tropical waters in southern China, with notes on their small-subunit rRNA gene sequences. Int J Syst Evol Microbiol 60, 234-243.

Chen, X., Li, Z., Hu, X. \& Kusuoka, Y. (2010b). Morphology, morphogenesis and gene sequence of a freshwater ciliate, Pseudourostyla cristata (Ciliophora, Urostyloidea) from the ancient Lake Biwa, Japan. Eur J Protistol 46, 43-60.

Guindon, S. \& Gascuel, O. (2003). A simple, fast, and accurate algorithm to estimate large phylogenies by maximum likelihood. Syst Biol 52, 696-704.

Hall, T. A. (1999). BioEdit: a user-friendly biological sequence alignment editor and analysis program for Windows 95/98/NT. Nucleic Acids Symp Ser 41, 95-98.

Hu, X., Song, W. \& Warren, A. (2002). Observations on the morphology and morphogenesis of a new marine urostylid ciliate, Parabirojimia similis nov. gen., nov. spec. (Protozoa, Ciliophora, Hypotrichida). Eur J Protistol 38, 351-364.

Hu, X., Hu, X., Al-Rasheid, K. A. S. \& Song, W. (2009). Reconsideration on the phylogenetic position of Epiclintes (Ciliophora, Stichotrichia) based on SSrRNA gene sequence and morphogenetic data. Acta Protozool 48, 203-211.

Kahl, A. (1932). Urtiere oder Protozoa I: Wimpertiere oder Ciliata (Infusoria) 3. Spirotricha. In Die Tierwelt Deutschlands und der angrenzenden Meeresteile, vol. 25, pp. 399-650. Jena: Gustav Fischer (in German).

Kumar, S., Tamura, K. \& Nei, M. (2004). MEGA3: integrated software for molecular evolutionary genetics analysis and sequence alignment. Brief Bioinform 5, 150-163.
Lei, Y., Choi, J. K., Xu, K. \& Petz, W. (2005). Morphology and infraciliature of three species of Metaurostylopsis (Ciliophora, Stichotrichia): M. songi n. sp., M. salina n. sp., and M. marina (Kahl 1932) from sediments, saline ponds, and coastal waters. J Eukaryot Microbiol 52, 1-10.

Li, L., Zhang, Q., Hu, X., Warren, A., Al-Rasheid, K. A., Al-Khedheiry, A. A. \& Song, W. (2009). A redescription of the marine hypotrichous ciliate, Nothoholosticha fasciola (Kahl, 1932) nov. gen., nov. comb. (Ciliophora: Urostylida) with brief notes on its cellular reorganization and SS rRNA gene sequence. Eur J Protistol 45, 237-248.

Lin, X. \& Song, W. (2004). A new marine ciliate, Erniella wilberti spec. nov. (Ciliophora: Hypotrichida), from shrimp culturing waters in North China. Acta Protozool 43, 55-60.

Lynn, D. H. (2008). The Ciliated Protozoa: Characterization, Classification and Guide to the Literature, 3rd edn. Dordrecht: Springer.

Nylander, J. A. A. (2004). MrModeltest version 2. Evolutionary Biology Centre, Uppsala University.

Page, R. D. M. (1996). TreeView: an application to display phylogenetic trees on personal computers. Comput Appl Biosci 12, 357-358.

Ronquist, F. \& Huelsenbeck, J. P. (2003). MrBayes 3: Bayesian phylogenetic inference under mixed models. Bioinformatics 19, 15721574.

Shao, C., Miao, M., Song, W., Warren, A., Al-Rasheid, K., Al-Quraishy, S. \& Al-Farraj, S. (2008a). Studies on two marine Metaurostylopsis spp. from China with notes on the morphogenesis of M. sinica nov. spec. (Ciliophora, Urostylida). Acta Protozool 47, 95-112.

Shao, C., Song, W., Al-Rasheid, K. A., Yi, Z., Chen, X., Al-Farraj, S. A. \& Al-Quraishy, S. A. (2008b). Morphology and infraciliature of two new marine urostylid ciliates: Metaurostylopsis struederkypkeae n. sp. and Thigmokeronopsis stoecki n. sp. (Ciliophora, Hypotrichida) from China. J Eukaryot Microbiol 55, 289-296.

Song, W. \& Wilbert, N. (2002). Faunistic studies on marine ciliates from the Antarctic benthic area, including descriptions of one epizoic form, 6 new species, and 2 new genera (Protozoa: Ciliophora). Acta Protozool 41, 23-61.

Song, W., Petz, W. \& Warren, A. (2001). Morphology and morphogenesis of the poorly-known marine urostylid ciliate, Metaurostylopsis marina (Kahl, 1932) nov. gen., nov. comb. (Protozoa, Ciliophora, Hypotrichida). Eur J Protistol 37, 63-76.

Swofford, D. L. (2002). PAUP*. Phylogenetic analysis using parsimony (*and other methods). Sunderland, MA: Sinauer Associates.

Wilbert, N. (1975). Eine verbesserte Technik der Protargolimprägnation für Ciliaten. Mikrokosmos 64, 171-179 (in German).

Wilbert, N. \& Song, W. (2005). New contribution to the marine benthic ciliates from the Antarctic area, including description of seven new species (Protozoa, Ciliophora). J Nat Hist 39, 935-973.

Xu, K., Lei, Y. \& Choi, J. K. (2006). Tunicothrix rostrata n. g., n. sp., a new urostylid ciliate (Ciliophora, Stichotrichia) from the Yellow Sea. J Eukaryot Microbiol 53, 485-493.

Yi, Z., Song, W., Shao, C., Warren, A., Al-Rasheid, K. A., Roberts, D. M., Miao, M., Al-Quraishy, S. A. \& Chen, Z. (2008). Phylogeny of some systematically uncertain urostyloids - Apokeronopsis, Metaurostylopsis, Thigmokeronopsis (Ciliophora, Stichotrichia) estimated with small subunit rRNA gene sequence information: discrepancies and agreements with morphological data. Eur $J$ Protistol 44, 254-262. 